\title{
Penentuan Aspek yang Berpengaruh Terhadap Produk Smartphone Berdasarkan Ulasan Berbasis Tekstual
}

\author{
http://dx.doi.org/10.28932/jutisi.v7i1.3466 \\ Riwayat Artikel \\ Received: 26 Februari 2021 | Final Revision: 22 Maret 2021 |Accepted: 25 Maret 2021 \\ Hetthroh Sagala $^{\# 1}$, Hapnes Toba ${ }^{\varpi^{* 2}}$ \\ "Program Studi Magister Ilmu Komputer, Fakultas Teknologi Informasi \\ UniversitasKristen Maranatha \\ Jl. Prof. drg. Surya Sumantri No.65 Bandung \\ ${ }^{1} 1879014$ emaranatha.ac.id \\ ${ }^{2}$ hapnestobalit.maranatha.edu
}

\begin{abstract}
With the rapid development of new technologies in smartphones, understanding market trends has become an increasingly difficult task. In these circumstances, online product reviews that can reflect consumer sentiment about the product has been a concern for now. Online review analysis can help sellers understand consumer interests and desires prior to launching a new product. This research contributes to determine the state of the smartphone's market by creating a method to find important aspects of a smartphone. The data source comes from the Amazon e-commerce web with four predefined smartphone brands. In this study, the authors used topic modeling with the LDA algorithm and sentiment analysis with VADER to find aspects of a smartphone and its sentiment classification. From the 10 scenarios made in this reserach, it was found out three aspects that always appear, namely: the screen, camera, and battery aspects. It is concluded that these three aspects are the most important of a smartphone based on textual reviews.
\end{abstract}

Keywords - Topic Modeling; Sentiment Analysis; LDA; ecommerce

\section{Pendahuluan}

Smartphone di era modern ini telah menempuh perjalanan panjang untuk menjangkau sampai di tahun 2021, dan telah berubah secara drastis di sepanjang jalan. Ini adalah evolusi yang telah menggemparkan pasar. Dalam dekade terakhir, resolusi layar smartphone meningkat 11 kali lipat [1], pemimpin pasar tradisional seperti merek Nokia keluar dari pasar smartphone sementara merek-merek inovatif seperti Apple, Samsung, Huawei mendirikan ekosistem bisnis baru di pasar. Dengan cepatnya perkembangan teknologi baru, memahami tren pasar telah menjadi tugas yang semakin sulit. Dalam keadaan ini, ulasan produk online atau bisa disebut sumber daya gratis yang mencerminkan sentimen konsumen tentang produk, saat ini menjadi perhatian.

Ulasan online adalah salah satu jenis sumber daya buatan pengguna yang populer dan penting, tempat pengguna dapat memublikasikan pengalaman dan pendapat mereka tentang produk, acara, atau layanan. Seiring aktivitas online yang terus berkembang, peran ulasan online menjadi semakin penting, terutama dalam proses pengambilan keputusan terkait tindakan pengguna di sistem online [2], [3].

Beberapa penelitian dalam [4], [5], dan [6] secara terus menerus menunjukkan bahwa kuantitas dan kualitas ulasan yang dibuat konsumen memiliki hasil yang berpengaruh positif pada niat pembeli dan menjadi sumber informasi utama bagi konsumen dan pemasar terkait kualitas produk. Namun, banyaknya ulasan online saat ini membuat proses penggalian informasi yang bermanfaat menjadi semakin sulit. Analisis ulasan online dapat membantu penjual dalam memahami minat dan keinginan konsumen sebelum meluncurkan produk baru.

Berdasarkan permasalahan di atas, penelitian ini mencoba untuk mencari tahu aspek yang berpengaruh dalam ulasan online. Topic modeling akan digunakan untuk menetukan aspek-aspek suatu merek smartphone. Selanjutkan akan dilakukan analisis sentimen terhadap aspek tersebut, sehingga dapat dikenali opini hasil ulasannya. Dataset untuk ulasan online ini akan diambil pada website Amazon dengan merek Apple, Samsung, Oneplus, dan Google Dengan demikian, hal yang akan menjadi tujuan utama dalam penelitian ini adalah untuk mengimplementasikan penggabungan topic modeling guna menemukan aspek yang berpengaruh atau paling banyak dibicarakan pada produk smartphone dengan analisis sentimen dalam ulasan online 
sehingga diperoleh perbandingan jumlah komentar bernuansa positif atau negatif untuk setiap aspek berpengaruh tersebut.

\section{KAJIAN LITERATUR}

\section{A. Penelitian Terkait}

Pada bagian ini akan dibahas beberapa teori yang berhubungan dengan penelitian yang dilakukan. Pada penelitian [7] sudah dilakukan analisis sentimen berbasis aspek pada website book hotel di website Tripadvisor dengan menggunakan LDA. Penelitian pada [8] menunjukkan analisis sentimen dengan menggunakan Valence Aware Dictionary dan sEntiment Reasoner (VADER). VADER memiliki performa analisis sentimen yang sangat baik, dengan nilai F1 Classification $=0,96$ dan Accuracy $=0,84$, masing-masing) pada teks di sosial media. Penelitian [9] menerapkan topic modeling berdasarkan latent dirichlet allocation (LDA) untuk menganalisis artikel artikel yang terdapat pada jurnal Organization Research Method (ORM) dan didapatkan sebanyak 15 topik dari 421 artikel yang cukup sesuai dari kajian yang dilakukan oleh manusia.

\section{B. Topic Modeling}

Dalam pembelajaran mesin dan pemrosesan bahasa alami, model topik adalah model generatif, yang menyediakan kerangka kerja probabilistik. Metode pemodelan topik umumnya digunakan untuk mengatur, memahami, mencari, dan meringkas arsip elektronik besar secara otomatis. "Topik" menandakan hubungan variabel yang tersembunyi, diperkirakan, yang menghubungkan katakata dalam kosakata dan kemunculannya dalam dokumen. Dokumen dipandang sebagai campuran topik. Topic modeling menemukan tema tersembunyi di seluruh koleksi dan membuat anotasi dokumen sesuai dengan tema tersebut. Setiap kata dipandang diambil dari salah satu topik tersebut. Sebuah distribusi cakupan dokumen topik dibuat dan memberikan cara baru untuk mengeksplorasi data pada perspektif topik [11]. Konsep Topic modeling ditunjukkan pada Gambar 1.

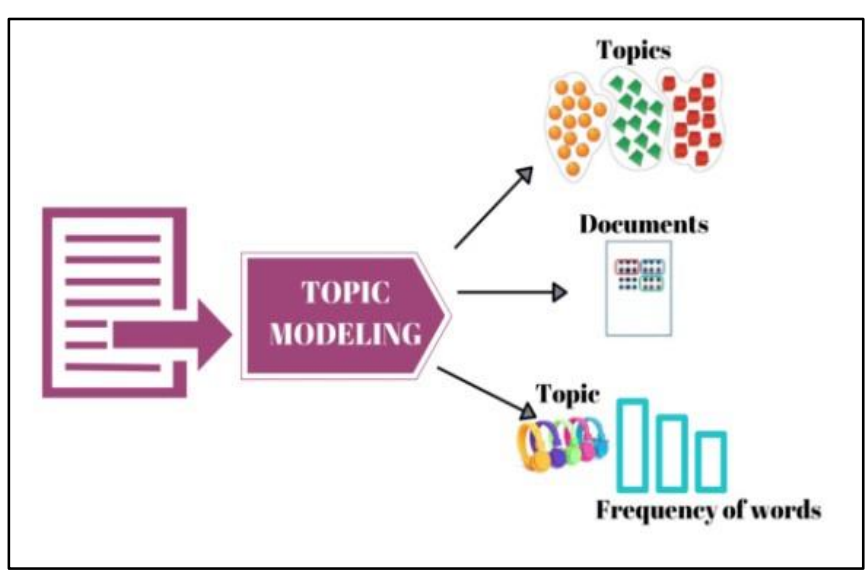

Gambar 1. Topic Modeling

\section{Latent Dirichlet Allocation (LDA)}

Dalam NLP, Latent Dirichlet Allocation (LDA) adalah teknik pemodelan topik yang secara otomatis menemukan topik dalam dokumen teks. LDA menganggap dokumen sebagai campuran dari berbagai topik dan setiap kata termasuk dalam salah satu topik dokumen. Algoritma ini pertama kali disajikan sebagai model grafis untuk penemuan topik [11]. LDA membayangkan serangkaian topik yang tetap. Setiap topik mewakili sekumpulan kata. Tujuan LDA adalah memetakan semua dokumen ke topik sedemikian rupa, sehingga kata-kata dalam setiap dokumen sebagian besar terkait dengan topik tersebut.

\section{Analisis Sentimen dengan VADER}

Analisis sentimen, juga disebut penambangan opini, adalah bidang studi yang menganalisis opini, sentimen, evaluasi, penilaian, sikap, dan emosi orang terhadap entitas seperti produk, layanan, organisasi, individu, masalah, peristiwa, topik, dan atributnya. Ini mewakili ruang masalah yang besar. Ada juga banyak nama dan tugas yang sedikit berbeda, misalnya, analisis sentimen, penambangan opini, ekstraksi pendapat, penambangan sentimen, analisis subjektivitas, analisis pengaruh, analisis emosi, penambangan review, dll. Namun, semuanya sekarang berada di bawah bagian analisis sentimen atau penambangan opini [12].

VADER termasuk dalam jenis analisis sentimen yang didasarkan pada leksikon kata-kata yang berhubungan dengan sentimen. Dalam pendekatan ini, setiap kata dalam leksikon dinilai apakah itu positif atau negatif, dan dalam banyak kasus, seberapa positif atau negatif. Pada Tabel I adalah salah satu contoh kutipan dari leksikon Vader, di mana semakin positif kata tersebut maka peringkat positif lebih tinggi dan semakin negatif kata tersebut maka peringkat negatifnya semakin lebih rendah.

TABEL I

RATING SENTIMEN VADER

\begin{tabular}{|l|c|}
\hline Word & Rating sentiment \\
\hline tragedy & $-3,4$ \\
\hline rejoiced & 2,0 \\
\hline insane & $-1,7$ \\
\hline disaster & $-3,1$ \\
\hline Great & 3,1 \\
\hline
\end{tabular}

VADER menganalisis sepotong teks yang diperiksa untuk melihat apakah ada kata-kata dalam teks yang ada dalam leksikon. Misalnya, kalimat "the atmosphere was great and the people rejoiced" memiliki dua kata dalam leksikon (baik dan bagus) dengan peringkat masing-masing 3,1 dan 2,0. VADER menghasilkan empat metrik sentimen dari suatu kalimat, yaitu positif, netral, negatif, dan skor compound yang mana adalah metrik terakhir hasil penjumlahan peringkat metrik sebelumnya yang akan di normalisasi ke 
dalam nilai -1 (paling negatif), 0 (neutral, dan lebih dari 0 sampai ke 1 (paling positif) [8].

\section{METODOLOGI PENELITIAN \& IMPLEMENTASI}

Pada bagian ini akan dijelaskan tentang metodologi yang akan digunakan dalam penyusunan penelitian ini. Gambar 2 menunjukkan diagram bagaimana dilakukan metode untuk mencari aspek sentimen yang penting dari produk smartphone.

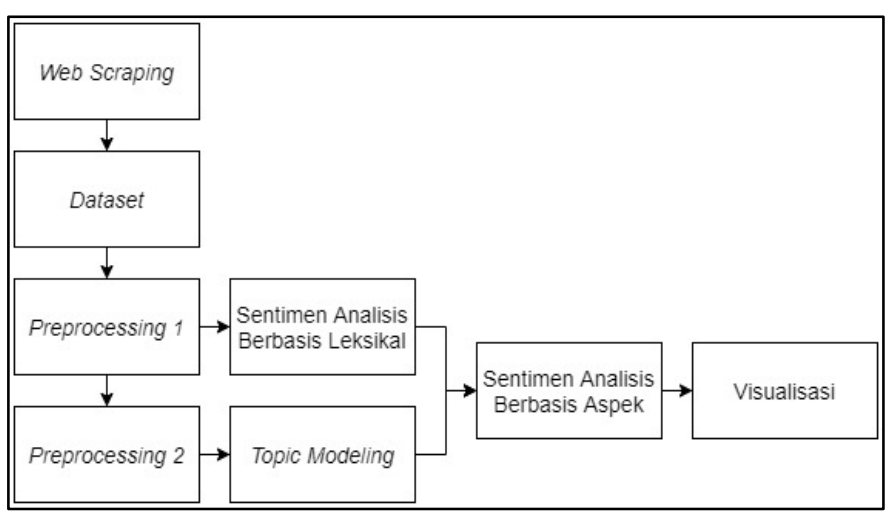

Gambar 2. Diagram Metodologi Penelitian

Proses pertama dalam penelitian ini adalah mengambil data, sumber data yang dipakai di penelitian ini berasal dari website e-commerce Amazon dengan tipe produk smartphone. Pengambilan data dilakukan dengan cara scraping melalui aplikasi web scraping pada browser chrome, setelah itu data disimpan dalam bentuk csv. Setelah dataset terkumpul, dilakukan preprocessing pada dataset yang akan menjadi input pada proses topic modelling dan analisis sentimen. Topic modeling dengan algoritma LDA digunakan untuk mencari aspek-aspek yang terkandung pada ulasan smartphone. Setelah mendapat aspek-aspek yang dominan dilakukan analisis sentimen dengan VADER sehingga mendapatkan analisis sentimen berbasis aspekaspek yang ditemukan. Tahap terakhir adalah visualisasi hasil analisis sentimen berbasis aspek pada tiap merek smartphone.

\section{A. Sumber Data}

Data yang digunakan adalah produk smartphone dari merek Apple, Samsung, Google, dan Oneplus yang diambil dari web e-commerce Amazon menggunakan aplikasi add-on Web scraper dari webscrapperio yang di instalasi pada browser Chrome. Gambar 3 menunjukkan alur diagram web scraping, dimulai dari membuat sitemap untuk web amazon, membuat dan memilih selector untuk mengambil data yang diinginkan pada start $\neg$ ᄀ_url yang dibuat, lalu menentukan parameter jeda waktu parameter dan interval saat ingin melakukan proses scraping. Setelah semua data selesai di scraping, Hasilnya akan disimpan dalam bentuk csv.

Jumlah data yang diambil berjumlah 51.782 data entry yang mencakup 4 merek, yaitu Apple, Samsung, Google dan
Oneplus dari model keluaran 2016 sampai 2019. Pada merek Apple ada 11 tipe yang diambil, yaitu iPhone 7, 7 Plus, 8, 8 Plus, X, XR, XS, 11, 11 Pro, dan 11 Pro Max. Merek Samsung diwakilkan dengan 14 tipe, yaitu Galaxy Note 8, 9, 10, 10 lite, 10+, 20, Galaxy S7 Edge, S8, S8+, S9, S0, S20, dan S20 Ultra. Untuk merek Google ada 7 tipe, yaitu Pixel 2 XL, $33 a$, 3 XL. 4, 4a, dan Pixel 5. Dan terakhir merek OnePlus yang diambil sebanyak 4 tipe, yaitu OnePlus 7 Pro, 7T, 8, dan 8 Pro.

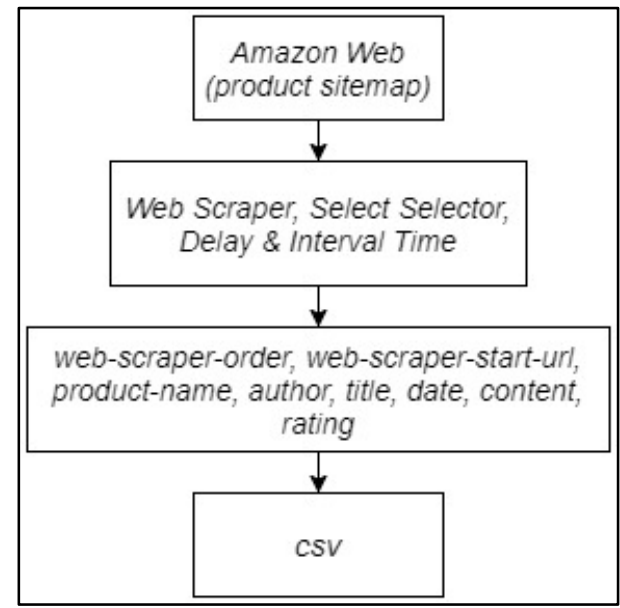

Gambar 3. Diagram Web Scraping

Kode pada Listing 1 memberikan penerapan web scraping dalam bentuk json. Nilai yang mengisi_id adalah nama dari sitemap yang dibuat, sedangkan start $\mathrm{Url}$ adalah link ulasan produk smartphone pada website Amazon yang ingin diambil. Dalam bagian selector ada id: Product name yang bertugas untuk mengambil nama produk smartphone. Nilai dalam id: Review wrapper adalah selector element untuk memilih daftar item apa saja yang ingin diambil.

Setelah itu ada id: author sebagai child element dari id: Review wrapper yang bertugas untuk mengambil nama pembeli smartphone tersebut, diikuti dengan id: title yang merupakan judul ulasan yang diberikan oleh author id date dimana lokasi dan tanggal ulasan tersebut terbit, id: content yang mana isi dari ulasan pengguna terhadap produk smartphone tersebut, dan id: rating adalah nilai bintang (1-5) yang diberikan oleh author. Pada id: Click Next adalah selector terakhir yang berfungsi untuk melakukan navigasi pada halaman ulasan berikutnya, lalu kembali lagi dengan proses yang sama dimulai dari id: Product name sampai ulasan yang ada diambil.

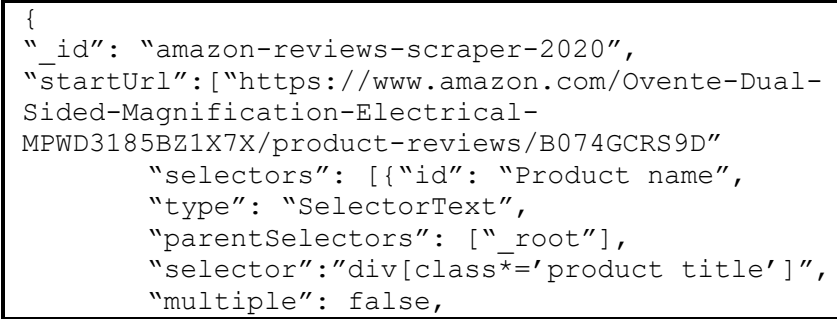




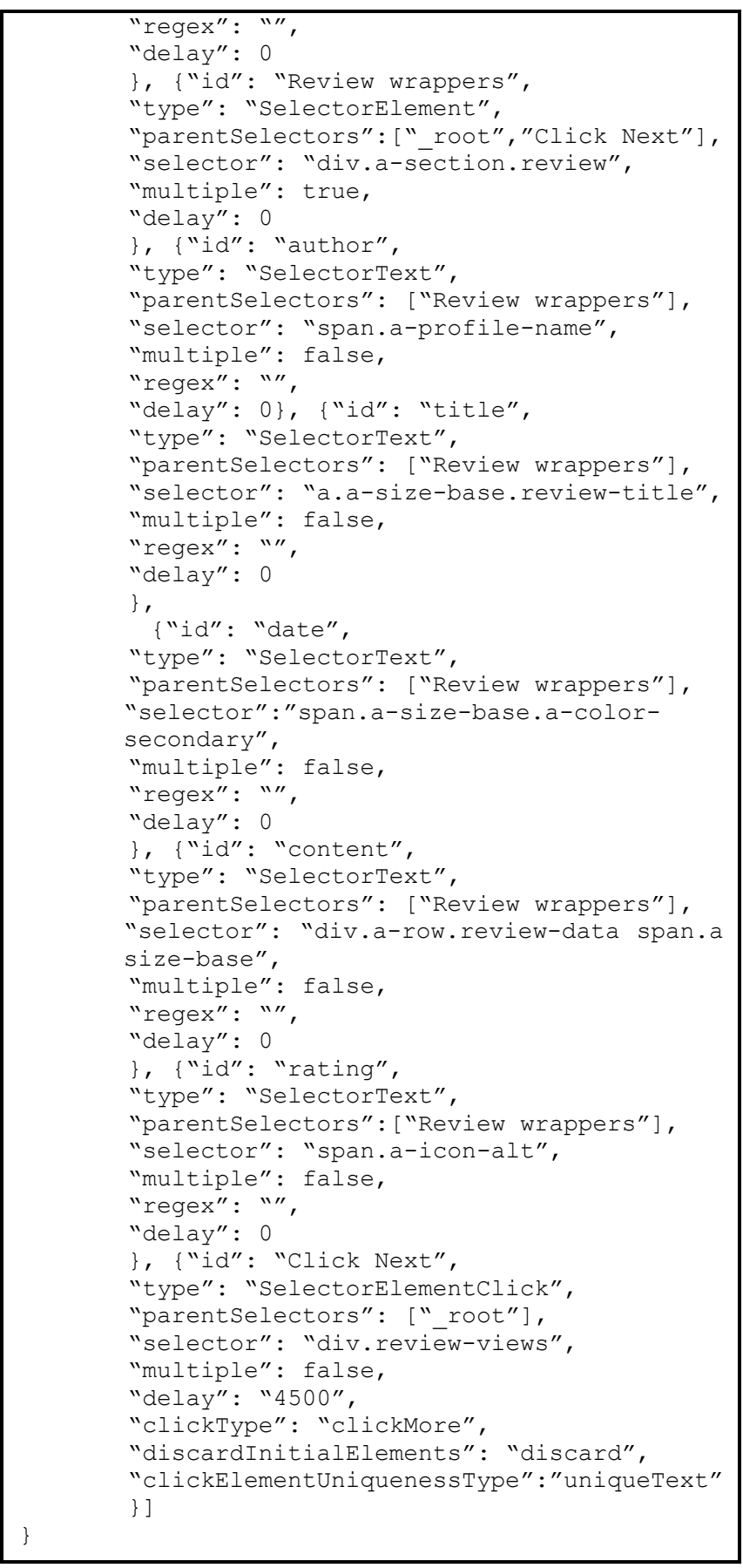

\section{Listing 1. Web Scraping}

\section{B. Topic Modeling}

Untuk mencari aspek-aspek pada produk smartphone, digunakan topic modeling, yang menggunakan algoritma LDA menggunakan library. Gambar 4 menjelaskan diagram alur untuk mendapatkan aspek suatu smartphone. Pada percobaan ini digunakan 10 jenis kondisi data sebagai input sebagaimana yang tertera pada Tabel II.
TABEL II.

JENIS SKENARIO DATASET

\begin{tabular}{|l|l|}
\hline Merek & Kondisi \\
\hline Semua Merek & $\begin{array}{l}\text { Noun Tag, Noun \& Adj } \\
\text { Tag }\end{array}$ \\
\hline Apple & $\begin{array}{l}\text { Noun Tag, Noun \& Adj } \\
\text { Tag }\end{array}$ \\
\hline Samsung & $\begin{array}{l}\text { Noun Tag, Noun \& Adj } \\
\text { Tag }\end{array}$ \\
\hline OnePlus & $\begin{array}{l}\text { Noun Tag, Noun \& Adj } \\
\text { Tag }\end{array}$ \\
\hline Google & $\begin{array}{l}\text { Noun Tag, Noun \& Adj } \\
\text { Tag }\end{array}$ \\
\hline
\end{tabular}

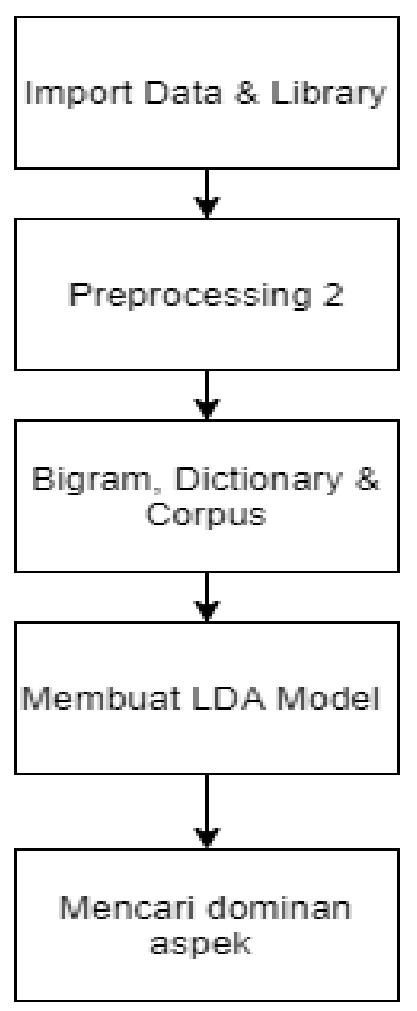

Gambar 4. Diagram Topic Modeling

\section{Preprocessing}

Setelah didapatkan 10 jenis kondisi data sebagai input, maka dilakukan pre-processing yang kedua dengan membuat semua teks menjadi huruf kecil (lowercase), menghapus teks dalam kurung siku, menghapus tanda baca, dan menghapus kata-kata yang mengandung angka. Setelah data cleaning dilakukan, setiap ulasan pada dataframe akan diubah menjadi bentuk list dan dilakukan tokenisasi untuk merubah bentuk kalimat menjadi menjadi kumpulan katakata berbentuk list. 
TABEL III

HASIL PROSES PREPROCCESSING STOPWORDS DAN LEMMATIZATION (NOUN)

\begin{tabular}{|c|l|}
\hline \multicolumn{1}{|c|}{ Sebelum Proses } & \multicolumn{1}{c|}{ Sesudah Proses } \\
\hline $\begin{array}{l}\text { 'an', 'amazing', 'purchase', } \\
\text { 'gamechanger'], ['the', 'phone', } \\
\text { 'came','as','described','in','cos } \\
\text { metically','it', 'had', 'the', } \\
\text { 'signs', 'of', 'good', 'use', 'with', } \\
\text { 'couple', 'of', 'scuffs', }\end{array}$ & $\begin{array}{l}\text { 'box', } \\
\text { ['workechaging',','flawless','couple',' } \\
\text { scuff' }\end{array}$ \\
\hline
\end{tabular}

Proses selanjutnya dilakukan proses penghilangan stopwords , membuat bigram, dan melakukan lemmatization dengan kondisi hanya kata benda $(N O U N)$ dan kata benda $(N O U N)$ dengan sifat $(A D J)$ saja. Hasil proses ini bisa dilihat pada Tabel III yang menunjukkan hanya kata benda saja yang diambil.

\section{Membuat input LDA (Dictionary \& Corpus)}

Untuk membuat model LDA dibutuhkan 2 input yaitu, dictionary (id2word) dan korpus dari proses sebelumnya. Dalam membuat dua bentuk input ini dilakukan dengan bantuan library Gensim dimana library ini membuat id unik untuk setiap kata pada dokumen beserta frekuensi kata tersebut di tiap dokumen. Contoh seperti pada Gambar 5, dimana $(0,2)$ menjelaskan 0 adalah id word yang muncul dua kali pada dokumen tersebut. Pada output selanjutnya bisa dilihat 0 adalah id untuk kata 'condition' di dokumen tersebut. Bentuk seperti itu yang akan dipakai sebagai input membuat model LDA. Pada bagian listing 2 adalah bagian untuk membuat input model LDA dengan bantuan Gensim.

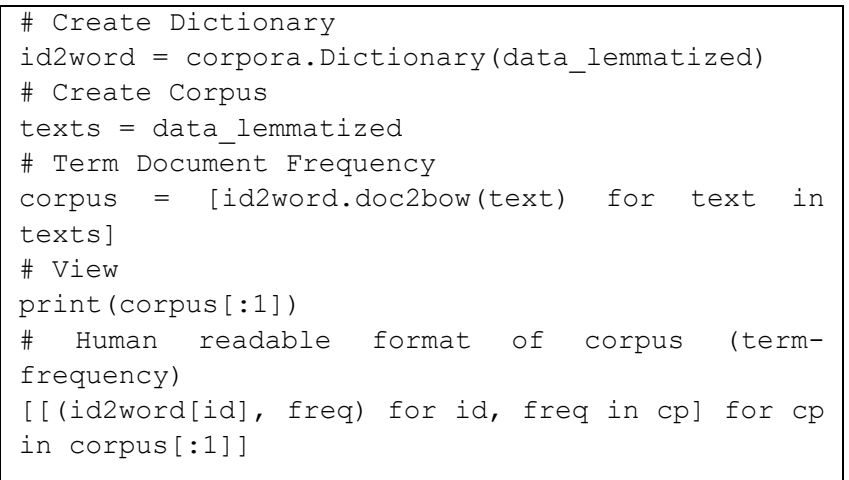

Listing 2. Membuat Input untuk Model LDA

$[[(0,2),(1,1),(2,1)]]$

] \# Human readable format of corpus (term-frequency)

[[(id2word[id], freq) for id, freq in $\mathrm{cp}$ ] for $\mathrm{cp}$ in corpus[:1]]

[[('condition', 2), ('ding', 1), ('side', 1)]]

Gambar 5. Hasil Pembentukan input LDA

\section{E. Membuat LDA Model}

Pada proses ini dilakukan pembuatan model LDA yang menggunakan input dictionary dan korpus yang sudah dibuat tadi. Parameter yang ditentukan dalam membuat model LDA terdapat pada Gambar 6. Paramater alpha adalah sebuah hyperparameter yang mempengaruhi ketersebaran topik, chunksize adalah seberapa banyak dokumen yang akan dipakai pada setiap training, update_every yang akan mempengaruhi seberapa sering parameter model akan diperbarui dan passes adalah parameter untuk menentukan seberapa banyak training yang dilakukan. Setelah model jadi akan dihitung nilai koherensinya untuk melihat seberapa baik model yang sudah dibuat.

Setelah proses model dibuat akan dicari jumlah topik yang paling optimal demgan cara membuat beberapa model LDA dengan jumlah topik yang berbeda dan memilih jumlah topik yang memiliki nilai koherensi tinggi. Koherensi topik adalah ukuran yang digunakan untuk mengevaluasi model topik: metode yang secara otomatis menghasilkan topik dari kumpulan dokumen, menggunakan model variabel laten. Setiap topik yang dihasilkan terdiri dari kata-kata, dan koherensi topik diterapkan ke $\mathrm{N}$ kata teratas dari topik tersebut. Ini didefinisikan sebagai rata-rata / median dari skor kemiripan kata berpasangan dari kata-kata dalam topik tersebut. Model yang baik akan menghasilkan topik yang koheren, yaitu topik dengan skor koherensi topik yang tinggi. Topik yang baik adalah topik yang dapat dideskripsikan dengan label pendek [13].

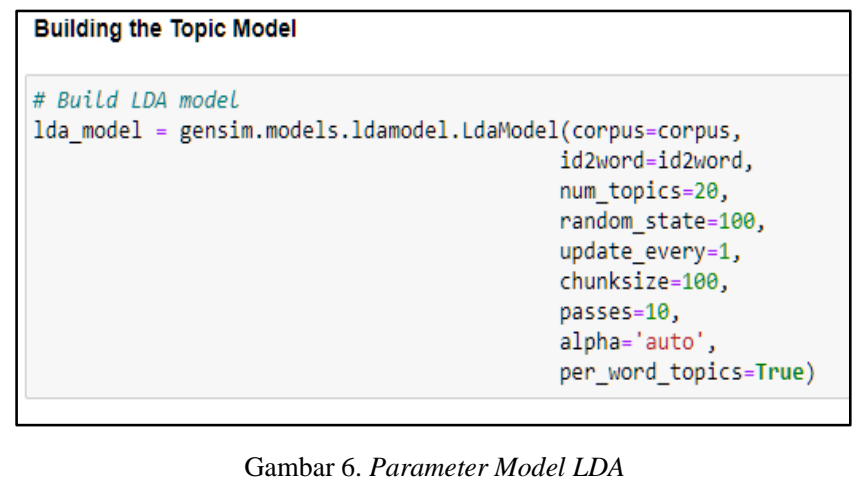

\section{F. Analisis Sentimen Berbasis Aspek}

Setelah aspek-aspek suatu smartphone didapatkan dengan bantuan LDA topic modeling, maka akan dilakukan proses analisis sentimen pada kolom 'review' yang ada pada dataframe hasil topic modeling dengan bantuan library $V A D E R$. Pada tahap ini tidak dilakukan pre-processing lebih lanjut dikarenakan $V A D E R$ dapat memberikan skor sentimen yang berbeda pada jenis teks yang ada. Tabel IV menunjukkan hasil akhir analisis sentimen terhadap aspek yang dominan untuk tiap ulasan yang diberikan oleh author, sehingga bisa dilihat sentimen untuk tiap ulasan berdasarkan aspeknya. Dataframe yang sudah jadi, disimpan dalam bentuk csv untuk selanjutnya divisualisasikan. 
TABEL IV

HASIL ANALISIS SENTIMEN BERBASIS ASPEK

\begin{tabular}{|c|c|c|c|c|c|}
\hline Model & Year & $\begin{array}{l}\text { Review } \\
\text { comments }\end{array}$ & Rate & Aspect & Sent \\
\hline $\begin{array}{l}\text { iPhone } \\
7 \text { Plus }\end{array}$ & 2019 & $\begin{array}{l}\text { phone came } \\
\text { in good } \\
\text { condition } \\
\text { came with } \\
\text { everyth... }\end{array}$ & 5 & screen & + \\
\hline $\begin{array}{l}\text { iPhone } \\
7 \text { Plus }\end{array}$ & 2020 & $\begin{array}{l}\text { excelente } \\
\text { producto.. }\end{array}$ & 1 & work & - \\
\hline $\begin{array}{l}\text { iPhone } \\
7 \text { Plus }\end{array}$ & 2018 & $\begin{array}{l}\text { This phone } \\
\text { came as } \\
\text { good and } \\
\text { screen... }\end{array}$ & 5 & screen & + \\
\hline $\begin{array}{l}\text { iPhone } \\
7 \text { Plus }\end{array}$ & 2018 & $\begin{array}{l}\text { little to no } \\
\text { scratches } \\
\text { looks } \\
\text { almost } \\
\text { brand } \\
\text { new ... }\end{array}$ & 4 & battery & + \\
\hline $\begin{array}{l}\text { iPhone } \\
7 \text { Plus }\end{array}$ & 2018 & $\begin{array}{l}\text { got it } \\
\text { yesterday } \\
\text { looks } \\
\text { almost new } \\
\text { works well } \\
t . .\end{array}$ & 5 & speaker & + \\
\hline $\begin{array}{l}\text { iPhone } \\
8 \text { Plus }\end{array}$ & 2019 & $\begin{array}{l}\text { So far, the } \\
\text { phone is } \\
\text { great... }\end{array}$ & 4 & condition & + \\
\hline $\begin{array}{l}\text { iPhone } \\
8 \text { Plus }\end{array}$ & 2020 & $\begin{array}{l}\text { LOVE IT. } \\
\text { Looks } \\
\text { amazing. } \\
\text { Refurbishe } \\
d \quad \text { great. } \\
\text { One little } \\
\text { scuff on the } \\
\text { top right } \\
\text { but that's ok } \\
\text { with me... }\end{array}$ & 4 & battery & + \\
\hline $\begin{array}{l}\text { iPhone } \\
8 \text { Plus }\end{array}$ & 2020 & $\begin{array}{l}\text { Turned } \\
\text { right on. } \\
\text { Delivered } \\
\text { quickly and } \\
\text { packaged } \\
\text { perfect. } \\
\text { Came with } \\
\text { wall peice } \\
\text { and... } \\
\end{array}$ & 5 & work & + \\
\hline $\begin{array}{l}\text { iPhone } \\
8 \text { Plus }\end{array}$ & 2019 & $\begin{array}{l}\text { Overall, } \\
\text { great phone } \\
\text { fast } \\
\text { Delivery } \\
\text { and... }\end{array}$ & 5 & condition & - \\
\hline
\end{tabular}

\section{HASIL EKSPERIMEN DAN EVALUASI}

A. Evaluasi Aspek dengan Noun Tag

Pada bagian ini akan dibahas hasil eksperimen dalam bentuk visualisasi dari dataset smartphone untuk semua merek maupun untuk masing-masing merek smartphone dengan Part of Speech (POS) Tag kata benda.

\section{A.1 Evaluasi Aspek Apple Smartphone Noun Tag}

Gambar 7 menunjukkan bahwa aspek screen adalah aspek yang paling dominan pada dokumen ulasan smartphone Apple diikuti dengan aspek baterai, brand, issue, purchase, work, phone, dan camera.

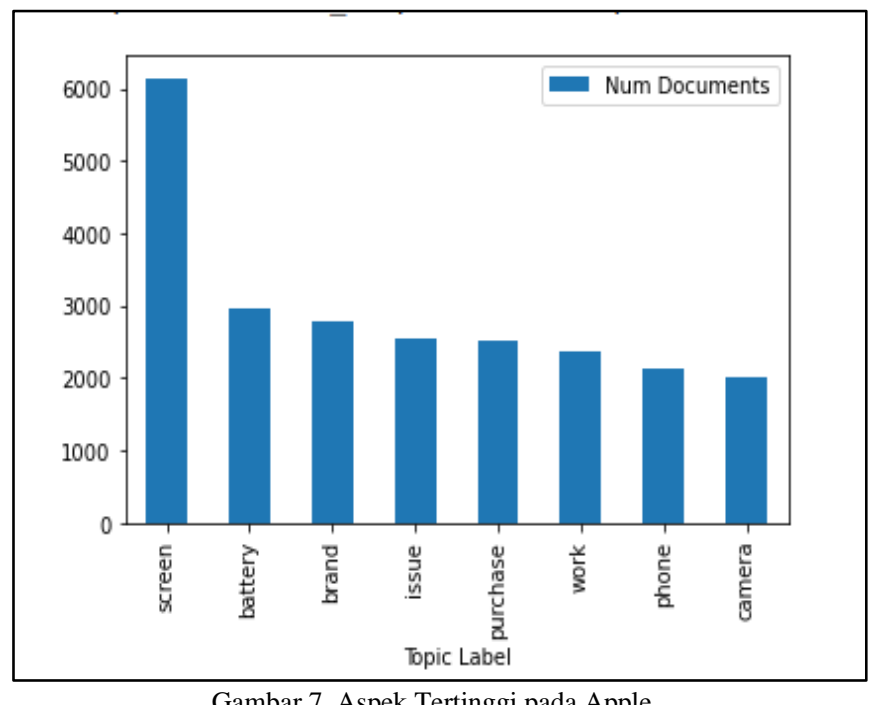

\section{A.2 Evaluasi Aspek Samsung Smartphone Noun Tag}

Gambar 8 menunjukkan bahwa camera adalah aspek yang paling dominan pada dokumen ulasan smartphone Samsung diikuti dengan aspek work, battery, charger, product, screen, phone, dan issue.

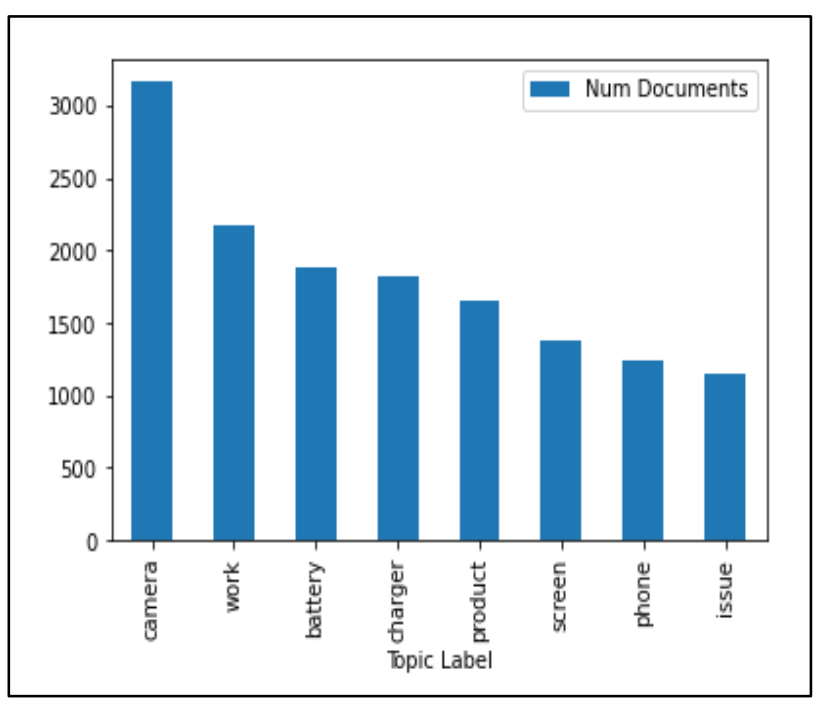

Gambar 8. Aspek Tertinggi pada Samsung 


\section{A.3 Evaluasi Aspek OnePlus Smartphone Noun Tag}

Gambar 9 menunjukkan bahwa product adalah aspek yang paling dominan pada dokumen ulasan smartphone OnePlus diikuti dengan aspek camera, battery, screen, issue, iphone, dan time.

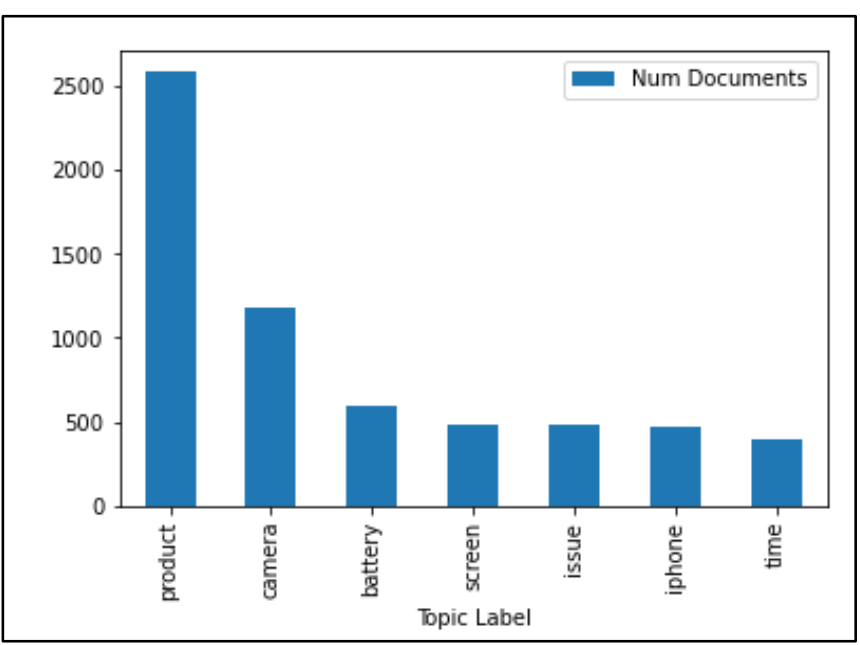

Gambar 9. Aspek Tertinggi pada OnePlus

\section{A.4 Evaluasi Aspek Google Smartphone Noun Tag}

Gambar 10 menunjukkan bahwa camera adalah aspek yang paling dominan pada dokumen ulasan smartphone Google diikuti dengan aspek battery, work, issue, phone, time, screen, dan app. Pada evaluasi ini bisa dilihat aspek screen, battery, dan camera selalu muncul di 4 merek smartphone tersebut.

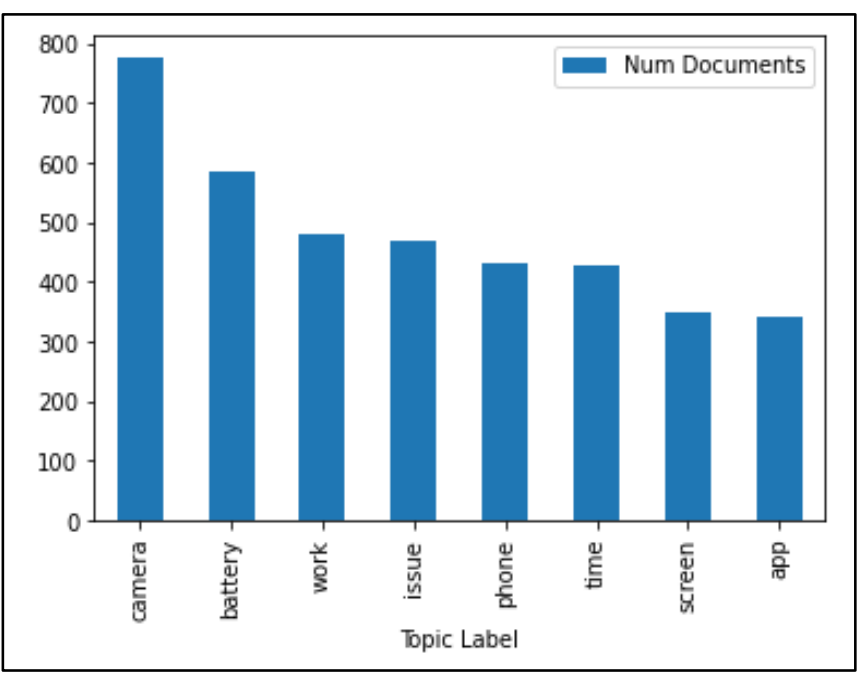

Gambar 10. Aspek Tertinggi pada Smartphone Google

\section{B. Analisis Sentimen Berbasis Aspek Pada Merek Apple}

Pada Gambar 11 sampai 14, grafik berwarna hijau menunjukkan sentimen positif sedangkan grafik berwarna merah menunjukkan sentimen negatif. Informsai pada sumbu $\mathrm{x}$ menujukkan merek smartphone dan sumbu y menunjukkan jumlah presentase analisis sentimen secara keseluruhan.

Pada Gambar 11 ditunjukkan hasil visualisasi analisis sentimen terhadap aspek merek Apple. Bisa dilihat aspek brand yang memiliki sentimen positif paling tinggi, sedangkan aspek issue yang memiliki sentimen negatif paling tinggi.

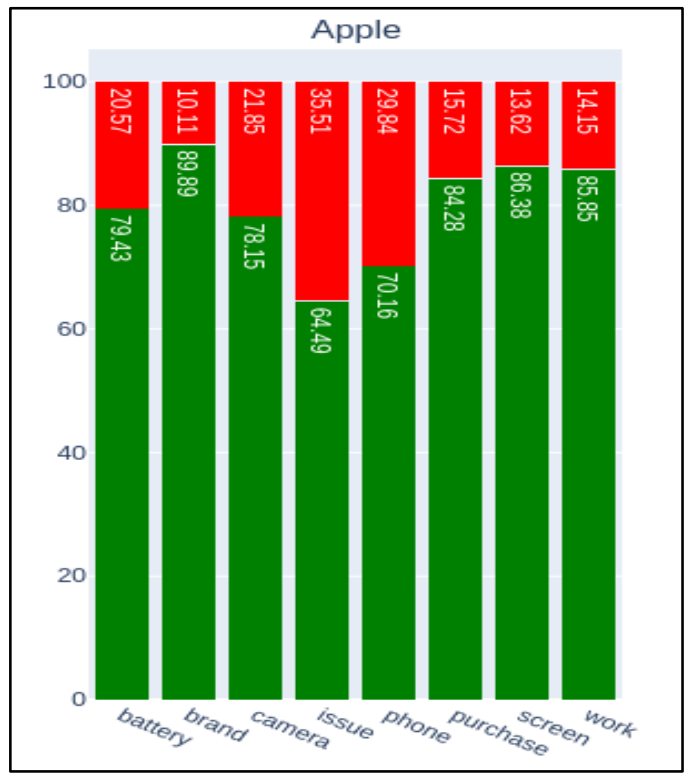

Gambar 11. Analisis Sentimen Berbasis Aspek pada Apple

\section{B.1 Analisis Sentimen Berbasis Aspek Pada Merek}

Samsung

Pada Gambar 12 ditunjukkan hasil visualisasi analisis sentimen terhadap aspek merek Samsung. Bisa dilihat aspek kamera yang memiliki sentimen positif paling tinggi, sedangkan aspek issue dan layar yang memiliki sentimen negatif paling tinggi.

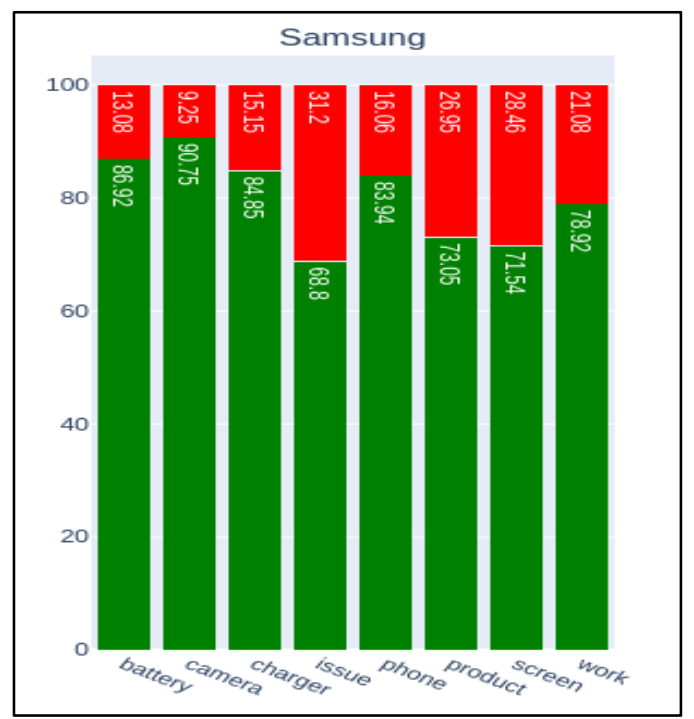

Gambar 12. Analisis Sentimen Berbasis Aspek pada Samsung 


\section{B.2 Analisis Sentimen Berbasis Aspek Pada Merek Oneplus}

Pada Gambar 13 ditunjukkan hasil visualisasi analisis sentimen terhadap aspek merek OnePlus. Bisa dilihat aspek product yang memiliki sentimen positif paling tinggi, sedangkan aspek issue memiliki sentimen negatif paling tinggi.

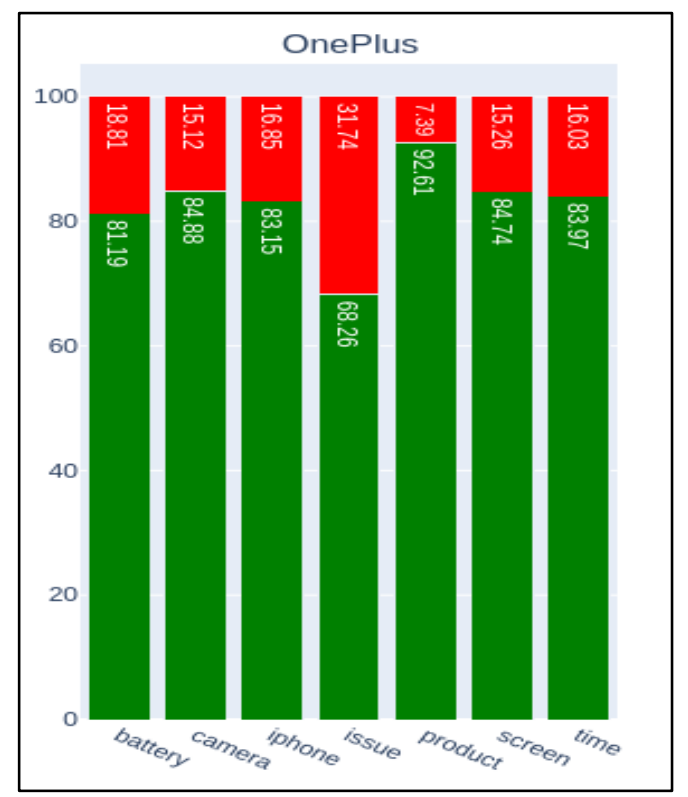

Gambar 13. Analisis Sentimen Berbasis Aspek pada OnePlus

\section{B.3 Analisis Sentimen Berbasis Aspek Pada Merek Google}

Pada Gambar 14 ditunjukkan hasil visualisasi analisis sentimen terhadap aspek merek Google. Bisa dilihat aspek kamera dan phone yang memiliki sentimen positif paling tinggi, sedangkan aspek issue memiliki sentimen negatif paling tinggi.

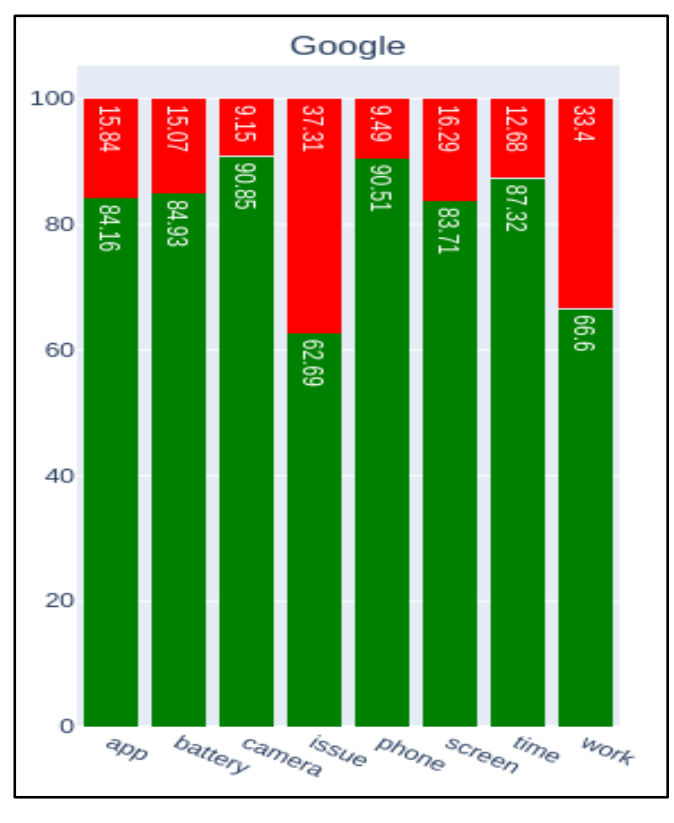

Gambar 14. Analisis Sentimen Berbasis Aspek pada Google

\section{Evaluasi Hasil}

Tabel V menunjukkan aspek-aspek yang didapatkan dari 10 skenario penelitian ini, sedangkan Tabel VI adalah potongan contoh dari tabel frekuensi kemunculan aspek terhadap 10 skenario pengambilan data yang ada. Dari 10 skenario yang dilakukan didapatkan 25 aspek unik yang muncul. Tiga aspek teratas yang selalu muncul dari skenario penelitian yang telah dilakukan adalah screen, battery dan camera.

TABEL V

ASPEK UNIK YANG DIDAPATKAN DARI 10 SKENARIO

\section{Aspek Unik}

screen, battery, brand, issue, purchase, work, phone, camera, charger, product, iphone, time, app, day, great, problem, unlocked, review, samsung, good, pro,feature, android, condition, love 
TABEL VI

FREKUENSI ASPEK YANG MUNCUL

\begin{tabular}{|c|c|c|c|c|c|}
\hline \multirow{2}{*}{ Skenario } & \multicolumn{5}{|c|}{ Aspek } \\
\cline { 2 - 6 } & Screen & Battery & Brand & Issue & Camera \\
\hline $\begin{array}{c}\text { Apple } \\
\text { noun }\end{array}$ & 1 & 1 & 1 & 1 & 1 \\
\hline $\begin{array}{c}\text { Samsung } \\
\text { noun }\end{array}$ & 1 & 1 & 0 & 1 & 1 \\
\hline $\begin{array}{c}\text { OnePlus } \\
\text { Noun }\end{array}$ & 1 & 1 & 0 & 1 & 1 \\
\hline $\begin{array}{c}\text { Google } \\
\text { Noun }\end{array}$ & 1 & 1 & 0 & 1 & 1 \\
\hline $\begin{array}{c}\text { Apple } \\
\text { noun adj }\end{array}$ & 1 & 1 & 1 & 0 & 1 \\
\hline $\begin{array}{c}\text { Samsung } \\
\text { noun adj }\end{array}$ & 1 & 1 & 0 & 0 & 1 \\
\hline $\begin{array}{c}\text { Oneplus } \\
\text { noun adj }\end{array}$ & 1 & 1 & 0 & 0 & 0 \\
\hline $\begin{array}{c}\text { Google } \\
\text { noun ajd }\end{array}$ & 1 & 1 & 0 & 0 & 0 \\
\hline $\begin{array}{c}\text { All brand } \\
\text { noun }\end{array}$ & 1 & 1 & 0 & 1 & 1 \\
\hline $\begin{array}{c}\text { All brand } \\
\text { adj }\end{array}$ & 1 & 0 & 0 & 1 & 1 \\
\hline $\begin{array}{c}\text { Total } \\
\text { aspek }\end{array}$ & 10 & 9 & 2 & 6 & 8 \\
\hline
\end{tabular}

Bisa dilihat aspek screen selalu ada di tiap skenario yang dilakukan diikuti oleh aspek battery dan camera. Dengan kata lain ketiga aspek tersebut dapat dianggap sebagai aspek yang paling berpengaruh pada smartphone dalam dataset penelitian ini. Jika digabungkan dengan analisis sentimen, pengguna maupun penggiat lainnya dapat memperoleh insight yang bermanfaat yang bisa dipakai untuk mengambil keputusan atau penelitian selanjutnya terkait dengan pemanfaatan ataupun pemasaran smartphone.

\section{KESIMPULAN DAN PENGEMBANGAN}

Implementasi topic modeling menggunakan algoritma LDA sudah berhasil dibuat untuk mencari aspek suatu smartphone. Pada penelitian ini didapatkan 3 aspek teratas yang selalu muncul dari skenario yang dilakukan yaitu screen, battery, dan camera, sehingga bisa disimpulkan pada penelitian ini bahwa 3 aspek tersebut yang menjadi aspek paling berpengaruh dalam suatu smartphone. Implementasi analisis sentimen juga sudah berhasil dilakukan sehingga menghasilkan analisis sentimen terhadap aspek-aspek suatu smartphone. Ditemukan dalam skenario tagging kata benda dan kata sifat, pengguna sering menggunakan kata kunci atau aspek 'great' dalam memberikan sentimen positif mereka terhadap smartphone yang diulas.

Untuk penelitian selanjutnya diusulkan untuk membangun model yang lebih spesifik atau menggunakan model yang dikembangkan secara langsung dengan penggabungan aspek dengan sentimennya (multi-classification). Pada proses automatic topic labeling juga bisa ditingkatkan dengan cara yang lain seperti menggunakan graph-based selain dengan menggunakan keyword tertinggi dari output LDA topic modeling. Diharapkan bahwa metoda kerja yang diusulkan melalui riset ini dapat bermanfaat untuk keperluan pemasaran produk selain smartphones.

\section{DAFTAR PUSTAKA}

[1] Bryant. Laurence. (2019) Ten Years of Mobile Evolution: A Look at the Samsung Galaxy $\mathrm{S}$ Series. [Online]. Tersedia: https://community.arm.com/developer/ipproducts/processors/b/proce ssors-ip-blog/posts/samsung-galaxy-sten-years-of-mobile-evolution.

[2] Nielsen. Online. (2015) 81 percent of online holiday shoppers read online customer reviews, according to nielsen online. [Online] Tersedia: http://www.nielsen-online.com/pr/pr-081218.pdf.

[3] A. Palmer. (2015) Web shoppers trust customer reviews more than friends. [Online]. Tersedia: http://www.adweek.com/news/ advertisingbranding/web-shoppers-trust-customer-reviews-morefriends-100313.

[4] D. H. Park, J. Lee, \& I. Han, "The effect of on-line consumer reviews on consumer purchasing intention: The moderating role of involvement," International Journal Electronic Commerce, vol. 11 no. 4, pp.125-148, July 2007

[5] Hu, N., Liu, L. \& Zhang, J.J, "Do online reviews affect product sales? The role of reviewer characteristics and temporal effects," Information Technology Management, vol. 9, 201-214, 2008.

[6] Park, D.H, Kim, S, "The effects of consumer knowledge on message processing of electronic word-of-mouth via online consumer reviews," Electronic Commerce Research and Appication, vol. 7, no. 4, pp. 399-410, December. 2008

[7] Akhtar, N., Zubair, N., Kumar, A. \& Ahmad, T, "Aspect based Sentiment Oriented Summarization of Hotel Reviews," Procedia Computer Science, vol. 115, pp. 563-571. Elsevier, 2017.

[8] Hutto, C. \& E. Gilbert, "VADER: A Parsimonious Rule-Based Model for Sentiment Analysis of Social Media Text," Prosiding International AAAI Conference on Web and Social Media, 2014, vol. 8 , no. 1 .

[9] A. Gaur, "Topic Models As A Novel Approach To Identify Themes In Content Analysis," Prosiding Academy of Management Proceedings, AOM 2017

[10] M. Blei., A. Ng., \& M. Jordan, "Probabilistic Topic Model," Communications of the ACM vol.55, no. 4, 2012.

[11] M. Blei, "Latent Dirichlet Allocation," Journal of Machine Learning Research, vol. 3, pp.993-1022., 2003.

[12] B. Liu, Sentiment Analysis and Subjectivity Handbook of Natural Language Processing, Cambridge, United Kingdom: Cambridge University Press, 2015.

[13] D. Newman, J.H. Lau, K. Grieser, \& T. Baldwin, "Automatic evaluation of topic coherence," Prosiding Human Language Technologies- North American Chapter of the Association for Computational Linguistics, 2010, pp. 100-108. 